日作紀（Jpn. J. Crop Sci.）83（3）：210-215（2014）

\title{
寒冷地における気温日較差が湛水直播水稲の出芽・苗立ちに及ぼす影響 一低温条件下で異なるコーティング種子を用いた解析一
}

\author{
古畑昌巳 ${ }^{1)} \cdot$ 原嘉隆 $^{2)}$ \\ (1) 農研機構中央農業総合研究センター北陸研究センター, ${ }^{2)}$ 農研機構九州沖縄農業研究センター)
}

\begin{abstract}
要旨: 前報では, 催芽種子と恒温器を利用して, 異なる気温, 気温日較差条件で湛水直播水稲の出芽 ・ 苗立ちを調査 した結果，気温日較差の影響は，播種後低温条件が播種後高温条件に比べて大きいこと，播種後低温条件では，気温 日較差が大きい区は気温日較差が小さい区に比べて生育量が大きくなることを明らかにした，本研究では，過酸化力 ルシウムコーティング種子, 鉄コーティング種子, 無コーティング種子を供試して試験を行った結果, 過酸化カルシ ウムコーティング種子は，鉄コーティング種子と無コーティング種子に比ベて出芽・苗立ちが優れ，気温日較差の影 響が小さいことが明らかとなった。また，播種後低温条件では，平均気温が同じであっても気温日較差が大きい区は， 気温日較差が小さい区に比べて出芽・苗立ちが早まって出芽・苗立ち率が向上するとともに生育量を確保しやすいこ と, 出芽時における出芽率の実測值とアレニウス式（温度依存反応式）による推定值はほほ同様の推移を示すことが, 供試したすべてのコーティング種子で確認された。
\end{abstract}

キーワード：アレニウス式，イネ，寒冷地，気温日較差，コーティング種子，出芽，湛水直播.

前報（古畑・原 2014）では，野外で防風区と無防風区を 設けて, 湛水土中直播水稲の出芽・苗立ちを調査した結果, 防風区では最高気温が上昇して気温日較差が大きくなった 条件で出芽・苗立ちの向上が認められた。ささらに, 恒温器 で催芽種子を供試して，異なる平均気温および気温日較差 条件下で湛水土中直播水稲の出芽・苗立ちを調査した結果, 高温条件では気温日較差の影響は小さく, 低温条件では気 温日較差の影響は大きい現象が認められ, さらに, 出芽時 に打ける出芽率の実測值とアレニウス式（温度依存反応 式）による推定值はほぼ同様の推移を示した.

現在, 過酸化カルシウムコーティング種子と播種後落水 管理を併用することによって湛水土中直播水稲の出芽・苗 立ちが向上・安定化することが全国各地で実証された結果， 条播抢よび点播様式の湛水土中直播栽培が耐倒伏性を高め る目的で北陸㧍よび東北地方を中心に導入が進んでいる. また，近年，鉄資材をコーティングした種子を利用した湛 水直播栽培が低コスト，鳥害回避の点から注目されている (山内 2004, 2005a, b)。このように, 実際に農家戋場で利 用されている過酸化カルシウム資材および鉄資材をコー ティングした種子を供試して, 出芽・苗立ちに及ぼす気温 日較差の影響を調查することは，普及地域の策定に資する かもしれない，また，前報で供試した催芽種子では出芽。 苗立ちに対する気温日較差の影響が認められたが、コー ティング種子条件では催芽種子と同様な気温日較差の影響 が認められるか明らかではない.

そこで，本研究では，異なるコーティング種子を供試し， 催芽種子と同様に出芽・苗立ちに対する影響が認められる か検証を行った。

\section{材料と方法}

北陸研究センター (新潟県上越市) 内の水田土壤 (細粒強 グライ土）を風乾砕土して, 容器に密封保管した。播種前 日に容器に入水して代かきを行い, ディスポカップ（500 $\mathrm{mL})$ に充填して 1 日間室内に静置し, 播種当日に表面水を 除去した。種子消毒後, $10^{\circ} \mathrm{C}$ で 5 日間浸種した後に $50 \%$ 程度発芽するまで催芽したコシヒカリの種子を供試し, 催 芽種子に対して, 過酸化カルシウム資材を乾籾重の等倍量 になるようにコーティングした種子(過酸化カルシウム コーティング区)，鉄資材（還元鉄粉 $90 \%$ と焼石亳 $10 \%$ の 割合で混合したもの) を乾籾重の等倍量になるようにコー ティングした種子 (鉄コーティング区), 資材をコーティン グしない種子 (無コーティング区) を作成した。なお，一 般的な鉄コーティング種子は, 気温 $15 \sim 20^{\circ} \mathrm{C}$ で消毒液に 24 時間, さらに水道水に $1 \sim 2$ 日浸種した後に乾燥させた 種子 (以下活性化種子) を利用する (山内 2004, 2005a, b). 活性化種子に鉄コーティングした種子は乾燥状態であり, 吸水過程を必要とするため, 催芽種子に鉄コーティングし た種子に比べて出芽・苗立ちが遅れる（古畑ら 2008）。また, 催芽種子でも鉄コーティングは過酸化カルシウムコーティ ングに比べて低温あるいは播種深が深い条件で出芽・苗立 ちは遅れ，最終的な出芽・苗立ち率は低下して初期生育量 は小さくなること（古畑ら 2009a）から，本実験の鉄コー ティングには活性化種子は適さないと判断し, 催芽種子を 用いた。なお，催芽種子に鉄コーティングすると発熱で発 芽率が低下する場合がある（古畑ら 2009b）が, 本実験では, 発熱で発芽率が低下しないように注意してコーティング し，保管した。それぞれのコーティング種子を 1 そップに

2014 年 1 月 22 日受理。連絡責任者：古畑昌巳 $\overline{\top 9} 943-0193$ 新潟県上越市稲田 1-2-1

TEL 025-523-4131, FAX 025-524-8578, furuhata@affrc.go.jp 
無
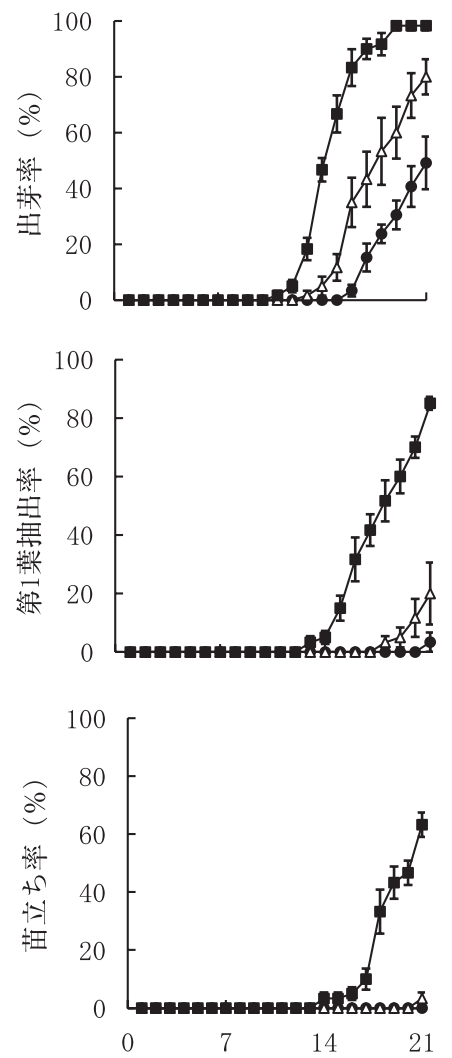

鉄
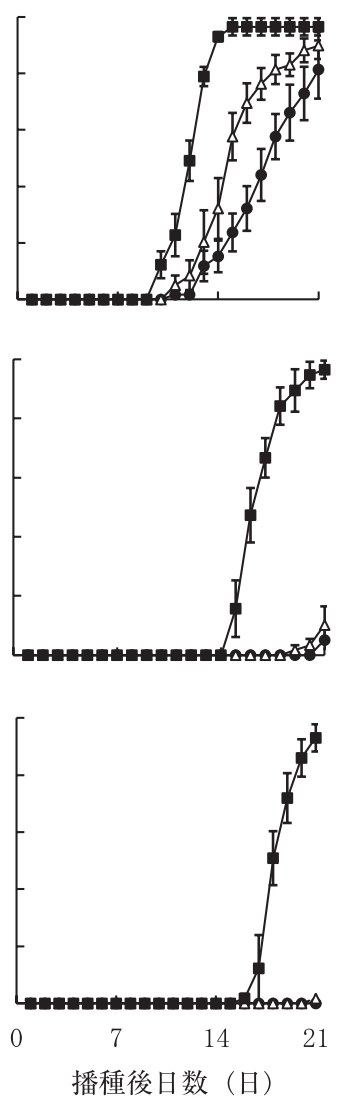

過酸化カルシウム
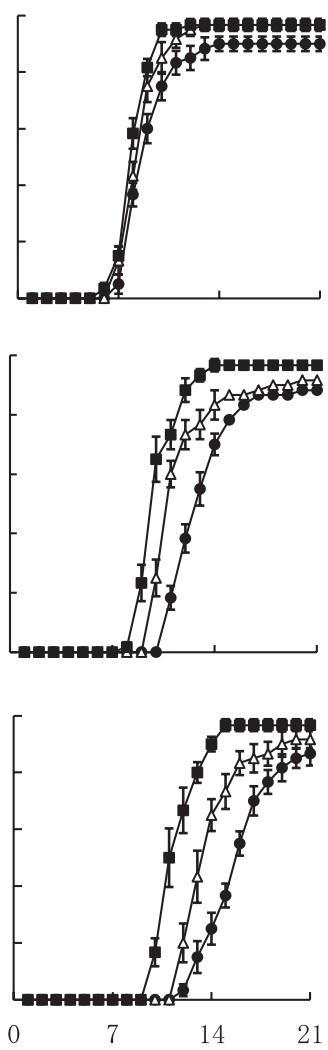

第 1 図 出芽率, 第 1 葉抽出率および苗立ち率の推移.

無：無コーティング区，鉄：鉄コーティング区，過酸化カルシウム：過酸化カルシウムコー

ティング区

日較差 $5^{\circ} \mathrm{C}, \triangle$ : 日較差 $10^{\circ} \mathrm{C}$

日較差 $15^{\circ} \mathrm{C}$. 縦棒は標準誤差 $(\mathrm{n}=6)$.

10 粒ずつ播種深 $1 \mathrm{~cm}$ で播種を行った。播種後のカップは, 明期（カップ上端において約 $100 \mu \mathrm{mol} \mathrm{m}^{-2} \mathrm{~s}^{-1}$ ) 12 時間，暗 期 12 時間, 平均気温 $15^{\circ} \mathrm{C}$, 気温日較差 (明期の気温と暗 期の気温の差) が $5^{\circ} \mathrm{C}, 10^{\circ} \mathrm{C} ， 15^{\circ} \mathrm{C}$ となるように設定した 恒温器内に静置した，播種後水管理は，播種数時間後に駒 込ピペットを用いて表面水を除去した後は落水条件とし た。なお，デイスポカップごとの水分むら，土壤表面の著 しい硬化 (土膜形成) とひび割れを抑える目的で，播種後 3 日目以降の毎日朝夕に湛水状態とならない程度に加水し， 小さなひび割れは加水の都度補修した。

調査は, 出芽個体数, 第 1 葉 - 第 2 葉抽出個体数の確認 を播種後毎日行った，播種後 5，7，10，14，21 日に，全 ての個体を採取し, 各個体の鞘葉長, 茎葉部乾物重を測定 し，播種後 21 日目には葉齢と草丈も測定した。長さの測 定においては屈曲している個体は伸ばして測定し，鞘葉が 地表面に出現した個体を出芽個体，第 2 葉を抽出した個体 を苗立ち個体とした、また，茎葉部乾物重の測定は，茎葉 部を $80^{\circ} \mathrm{C}$ で 3 日間乾燥させた後, 行った。出芽個体数, 第 1 葉抽出個体数挹よび苗立ち個体数, 茎葉部乾物重につい ては 6 反復 $(6$ カップ) の平均值を求め, 鞘葉長, 葉齢, 草 丈は 1 カップ内の 10 個体の平均值を求めて, さらにこれ
らの 6 反復 $(6$ カップ) の平均值を算出した．さらに播種か ら出芽・苗立ちまでの平均日数を比較するため，出芽個体 数のデー夕を用いて既報（古畑ら 2005）と同様に, 平均出 芽日数, 平均第 1 葉抽出日数抒よび平均苗立ち日数を算出 した.

出芽率の推定は以下の手順によった。まず，原（2010） の方法に従い, 明期の気温 $\left(\mathrm{T}_{\mathrm{L}}\right)$, 暗期の気温 $\left(\mathrm{T}_{\mathrm{D}}\right)$, 気体 定数 (R) の值を $8.31 \mathrm{~J} \mathrm{~K}^{-1} \mathrm{~mol}^{-1}$, 活性化エネルギー $(\mathrm{E})$ の 值を $88 \mathrm{~kJ} \mathrm{~mol}^{-1}$ として, 変換比率を以下の式で求めた.

変換比率 $=\exp \left(\left(1 /(273.15+25)-1 /\left(273.15+\mathrm{T}_{\mathrm{L}}\right)\right) \times\right.$ $\mathrm{E} / \mathrm{R}) / 2+\exp \left(\left(1 /(273.15+25)-1 /\left(273.15+\mathrm{T}_{\mathrm{D}}\right)\right) \times \mathrm{E} /\right.$ R) $/ 2$

この変換比率を利用して，ロジスティック関数に当ては めて推定值を計算し，推定值と実測值の差の二乗が最少と なる場合のロジスティック関数とアレニウス式のパラメー 夕を表計算ソフトウエア (Excel) のソルバーを用いて求 めた。

\section{結 果}

播種後に適宜土䁃表面に加水しながら落水状態とした土 壤は, 播種後日数の経過に伴って乾燥が緩やかに進んだが, 
第 1 表 異なるコーティング種子, 気温日較差が播種後 21 日目の出芽率, 第 1 葉抽出率および 苗立ち率 (\%)に及ぼす影響.

\begin{tabular}{ccccc}
\hline \multirow{2}{*}{$\begin{array}{c}\text { 生育 } \\
\text { ステージ }\end{array}$} & $\begin{array}{c}\text { 日較差 } \\
\left({ }^{\circ} \mathrm{C}\right)\end{array}$ & $\begin{array}{c}\text { 無 } \\
\text { コーティング }\end{array}$ & $\begin{array}{c}\text { 鉄 } \\
\text { コーティング }\end{array}$ & $\begin{array}{c}\text { 過酸化カルシウム } \\
\text { コーティング }\end{array}$ \\
\cline { 3 - 5 } & 5 & $49.2 \mathrm{a}$ & $81.4 \mathrm{a}$ & $90.0 \mathrm{a}$ \\
出芽 & 10 & $80.0 \mathrm{~b}$ & $89.9 \mathrm{a}$ & $96.7 \mathrm{a}$ \\
& 15 & $98.3 \mathrm{~b}$ & $96.5 \mathrm{a}$ & $96.7 \mathrm{a}$ \\
\hline \multirow{2}{*}{ 第 1 葉抽出 } & 5 & $3.4 \mathrm{a}$ & $5.1 \mathrm{a}$ & $88.3 \mathrm{a}$ \\
& 10 & $20.0 \mathrm{a}$ & $10.2 \mathrm{a}$ & $91.7 \mathrm{a}$ \\
& 15 & $85.0 \mathrm{~b}$ & $96.5 \mathrm{~b}$ & $96.7 \mathrm{a}$ \\
\hline 苗立ち & 5 & $0.0 \mathrm{a}$ & $0.0 \mathrm{a}$ & $86.7 \mathrm{a}$ \\
& 10 & $3.3 \mathrm{a}$ & $1.7 \mathrm{a}$ & $91.7 \mathrm{a}$ \\
& 15 & $63.3 \mathrm{~b}$ & $93.0 \mathrm{~b}$ & $96.7 \mathrm{a}$ \\
\hline
\end{tabular}

各コーティング区それぞれの生育ステージにおいて, 同一英文字間には $5 \%$ 水準の有意差が無 いことを示す (Tukey 法).

第 2 表 異なるコーティング種子, 気温日較差が出芽, 第 1 葉抽出および苗立ちまでの日数（日） に及ぼす影響。

\begin{tabular}{ccccc}
\hline \multirow{2}{*}{$\begin{array}{c}\text { 生育 } \\
\text { ステージ }\end{array}$} & $\begin{array}{c}\text { 日較差 } \\
\left({ }^{\circ} \mathrm{C}\right)\end{array}$ & $\begin{array}{c}\text { コーテ無 } \\
\text { コーティング }\end{array}$ & $\begin{array}{c}\text { 鉄 } \\
\text { コーティング }\end{array}$ & $\begin{array}{c}\text { 過酸化カルシウム } \\
\text { コーティング }\end{array}$ \\
\cline { 3 - 5 } & 5 & $17.1 \mathrm{a}$ & $16.1 \mathrm{a}$ & $9.2 \mathrm{a}$ \\
出芽 & 10 & $16.3 \mathrm{a}$ & $15.2 \mathrm{a}$ & $8.8 \mathrm{ab}$ \\
& 15 & $15.2 \mathrm{~b}$ & $12.8 \mathrm{~b}$ & $8.4 \mathrm{~b}$ \\
\hline 第 1 葉抽出 & 5 & - & - & $13.2 \mathrm{a}$ \\
& 10 & - & - & $11.6 \mathrm{~b}$ \\
& 15 & 16.1 & - & $10.4 \mathrm{c}$ \\
\hline 苗立ち & 5 & - & - & $15.4 \mathrm{a}$ \\
& 10 & - & 18.1 & $12.0 \mathrm{c}$ \\
\hline
\end{tabular}

各コーティング区それぞれの生育ステージにおいて，同一英文字間には $5 \%$ 水準の有意差が無 いことを示す (Tukey 法).

播種後 21 日目の調査終了時の乾燥程度は, 土壤表面に大 きなひび割れが生じない程度であった。

出芽率，第 1 葉抽出率拉よび苗立ち率の推移を第 1 図に 示した。すべての区で気温日較差が大きいほど出芽が早ま る傾向となった，出芽の遅速の気温日較差による差は，過 酸化カルシウムコーティング区では小さく, 鉄コーティン グ区および無コーティング区では大きかった。第 1 葉抽出 および苗立ちの遅速も出芽と同様の傾向となったが，気温 日較差による差がより顕著となった。

播種後 21 日目の出芽率, 第 1 葉抽出率および苗立ち率 を第 1 表に示した. 出芽率の種子コーティングによる差は, 気温日較差が大きい条件では小さく, 気温日較差が小さい 条件では大きい傾向となった，また，どの区でも気温日較 差が大きいほど出芽率が高い傾向となったが, 気温日較差 による出芽率の差は過酸化カルシウムコーティング区で小 さく, 鉄コーティング区と無コーティング区で大きかった.
さらに，第 1 葉抽出率および苗立ち率についても出芽率と 同様の傾向となったが, 気温日較差による差がより顕著と なった。

出芽〜苗立ち日数を第 2 表に示した。平均出芽日数は, 同じ気温日較差条件では, 過酸化カルシウムコーティング 区，鉄コーティング区，無コーティング区の順に短い傾向 となった。また，どの区でも気温日較差が大きいほど平均 出芽日数が短い傾向となった.

鞘葉長の推移を第 2 図に示した。過酸化カルシウムコー ティング区では気温日較差による鞘葉長の差は小さかっ た．また，鉄コーティング区と無コーティング区では気温 日較差による鞘葉長の差は大きく, 気温日較差が大きいほ ど鞘葉が長く推移する傾向となった。

播種後 21 日目の葉齢㧍よび草丈を第 3 表に示した。過 酸化カルシウムコーティング区では, 草丈は日較差が大き いほど大きい傾向となったが, 葉齢は日較差 $15^{\circ} \mathrm{C}$ のみ有 

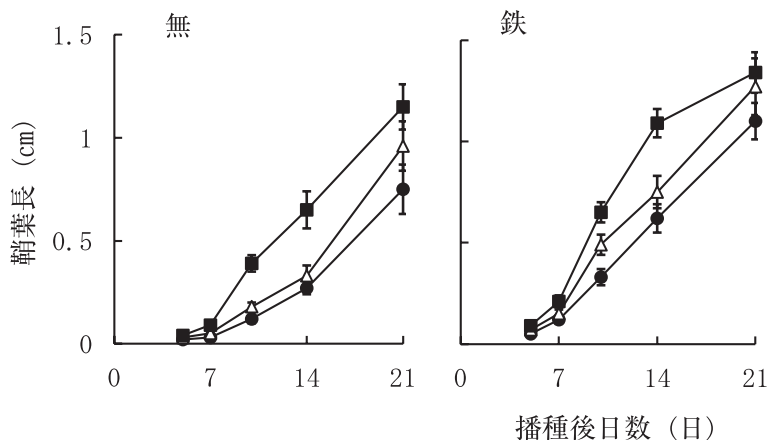

過酸化カルシウム

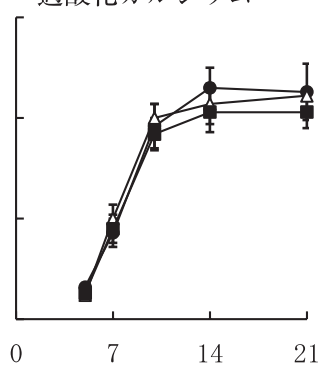

第 2 図鞘葉長の推移.

無：無コーティング区, 鉄 : 鉄コーティング区, 過酸化カルシウム：過酸化カルシ ウムコーティング区．：日較差 $5^{\circ} \mathrm{C}, \triangle$ : 日較差 $10^{\circ} \mathrm{C}$ 標準誤差 $(n=6)$.

第 3 表 異なるコーティング種子，気温日較差が播種後 21 日目の葉齢および草丈 $(\mathrm{cm})$ に 及ぼす影響。

\begin{tabular}{ccccc}
\hline & $\begin{array}{c}\text { 日較差 } \\
\left({ }^{\circ} \mathrm{C}\right)\end{array}$ & $\begin{array}{c}\text { 無 } \\
\text { コーティング }\end{array}$ & $\begin{array}{c}\text { 鉄 } \\
\text { コーティング }\end{array}$ & $\begin{array}{c}\text { 過酸化カルシウム } \\
\text { コーティング }\end{array}$ \\
\cline { 3 - 5 } & 5 & - & - & $1.8 \mathrm{a}$ \\
葉齢 & 10 & $0.3 \mathrm{a}$ & $0.1 \mathrm{a}$ & $1.8 \mathrm{a}$ \\
& 15 & $1.4 \mathrm{~b}$ & $1.9 \mathrm{~b}$ & $2.8 \mathrm{~b}$ \\
\hline \multirow{3}{*}{ 草丈 } & 5 & - & - & $2.9 \mathrm{a}$ \\
& 10 & - & - & $4.3 \mathrm{~b}$ \\
& 15 & 1.5 & 1.9 & $6.4 \mathrm{c}$ \\
\hline
\end{tabular}

各コーティング区の葉齢，草丈それぞれにおいて，同一英文字間には $5 \%$ 水準の有意差が 無いことを示す (Tukey 法).

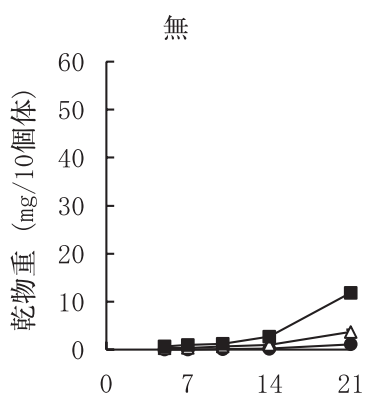

第 3 図茎葉部乾物重の推移.

無：無コーティング区，鉄：鉄コーティング区，過酸化カルシウム：過酸化カ ルシウムコーティング区 縦棒は標準誤差 $(\mathrm{n}=6)$.

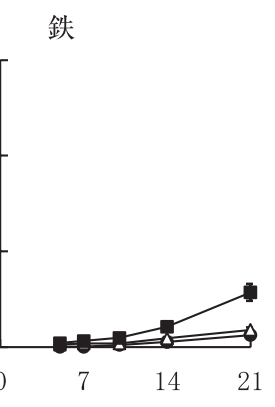

播種後日数（日）
過酸化カルシウム

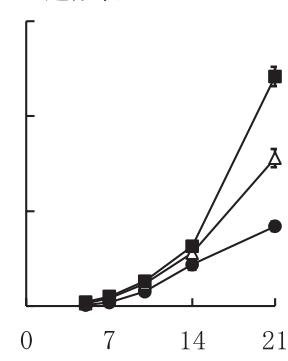

意に大きかった.

荃葉部乾物重の推移を第 3 図に示した。どの区でも気温 日較差が大きいほど茎葉部乾物重が大きく推移する傾向と なった。

出芽率の推移と数式の当てはめを第 4 図に示した。各試 験区でデータのばらつきを示す平均二乗誤差 (この值が小
さいほど推定精度が高い) は, 過酸化カルシウムコーティ ング区では，日較差 $15^{\circ} \mathrm{C}$ 区が $2.0 \%$ ，日較差 $10^{\circ} \mathrm{C}$ 区が $1.2 \%$ ，日較差 $5{ }^{\circ} \mathrm{C}$ 区が $0.9 \%$ ，鉄コーティング区では， 日較差 $15^{\circ} \mathrm{C}$ 区が $4.1 \%$, 日較差 $10^{\circ} \mathrm{C}$ 区が $2.1 \%$, 日較差 $5^{\circ} \mathrm{C}$ 区が $2.6 \%$ ，無コーティング区では，日較差 $15^{\circ} \mathrm{C}$ 区が $1.9 \%$ ，日較差 $10^{\circ} \mathrm{C}$ 区が $2.1 \%$, 日較差 $5^{\circ} \mathrm{C}$ 区が $2.6 \%$ と 


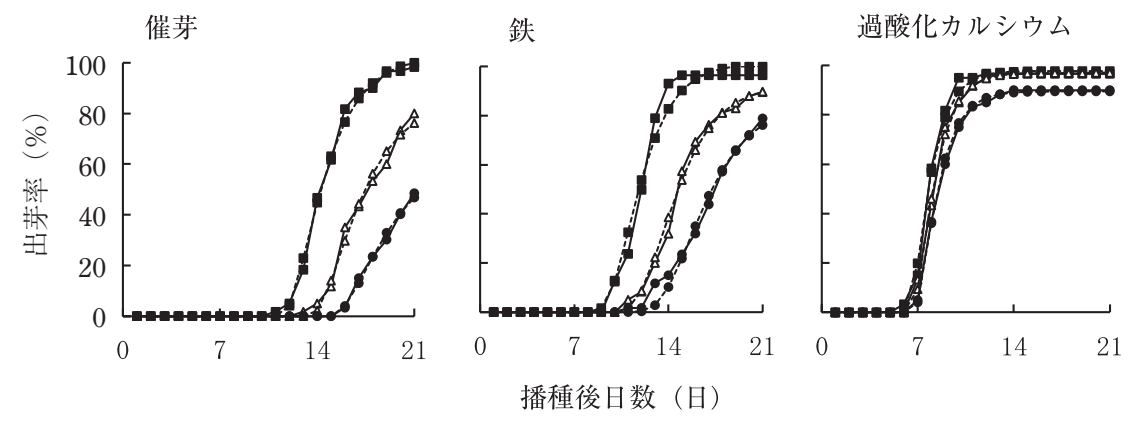

第 4 図 出芽率の推移とアレニウス式による推定.

無：無コーティング区，鉄：鉄コーティング区，過酸化カルシウム：過酸化カルシウ ムコーティング区. ○：日較差 $5^{\circ} \mathrm{C}, \triangle$ : 日較差 $10^{\circ} \mathrm{C}, \square$ : 日較差 $15^{\circ} \mathrm{C}$. 実線は実 測值，点線は推定值を示す.

なり，推定值の推移は，実測值とほぼ同様の推移を示した． また, すべての区で日較差 $15^{\circ} \mathrm{C}$ の出芽が最も早く, 次い で日較差 $10^{\circ} \mathrm{C}$ となり, 日較差 $5{ }^{\circ} \mathrm{C} か ゙$ 最も遅い傾向となった。

\section{考察}

本研究で異なるコーティング水稲種子を供試した結果, すべての区で，気温日較差が大きい場合に出芽・苗立ちが 早まる傾向を示し(第 1 図, 第 2 表), 播種後 21 日目の出芽. 苗立ち率も高まり (第 1 表), 茎葉部乾物重も大きく推移す る傾向を示した (第 3 図)。この結果は, 低温条件では種子 のコーティング処理に関わらず気温日較差が大きい場合に 出芽・苗立ちが優れることを示唆しており, 前報（古畑・ 原 2014）の過酸化カルシウムコーティング種子を利用した 野外試験，および催芽種子を利用した室内試験でそれぞれ 得られた結果と同様の結果となった。

前報（古畑・原 2014）では, 過酸化カルシウムコーティ ング種子を利用した野外試験，および催芽種子を利用した 室内試験をそれぞれ行った結果，いずれの試験でも気温日 較差が水稲の出芽・苗立ちに影響したが，別々の試験のた め，コーティング資材の効果は明らかにできなかった。そ こで, 本研究を行った結果, 過酸化カルシウムコーティン グ区は他区に比べて，以下のような傾向がみられた。すな わち，気温日較差の大小によらず他区に比べて鞘葉の伸長 が速く(第 2 図)，出芽·苗立ちが早まり（第 1 図，第 2 表), 播種後 21 日目の出芽・苗立ち率が高く(第 1 表)，草丈の 伸長と葉齢の進展が促進され (第 3 表), 茎葉部乾物重が大 きく推移した(第 3 図)。また，過酸化カルシウムコーティ ング区は，他区に比べて鞘葉の伸長 (第 2 図), 出芽の遅速 (第 1 図, 第 2 表),播種後 21 日目の出芽・苗立ち率 (第 1 表) への気温日較差の影響が小さかった。これらの結果は, 過 酸化カルシウムコーティング種子は，播種時期が低温かつ 気温日較差が異なる気象条件においても出芽・苗立ちが優 れていることを示唆しており，寒冷地での栽培に適してい ると考えられる。また実際に，寒冷地である東北・北陸地 域の湛水直播栽培面積は全国の湛水直播栽培面積の約 77\% を占めて抢り（農林水産省 2013）, その多くは過酸化カル
シウムコーティング種子を利用している，今後，北陸地方 の複数地点での連絡試験において, 過酸化カルシウムコー ティング種子を利用した湛水直播栽培の出芽・苗立ちと各 地点の播種条件および気象条件を併せた解析を行い, 吉永 ら（2007）が東北地方で行ったように過酸化カルシウムの コーティング量, 播種深度, 出芽期の気温, 播種後水管理 等の各種条件と出芽・苗立ちとの関係を整理できれば，北 陸地方での湛水直播栽培の出芽 ·苗立ち率を現状より向上 させてかつ安定させることにつながるかもしれない，

本研究では, 湛水直播水稲の出芽時に扔ける出芽率の実 測值とアレニウス式による推定值はほぼ同様の推移を示す ことが，供試したすべての区で確認された(第 4 図)。この 結果は，アレニウス式を利用することによって，異なる気 象条件で湛水直播栽培したイ亲の出芽・苗立ちの推移を推 定できる可能性を示している。また，出芽・苗立ちに最低 限必要とされる気温やエネルギー量が分かれば，気象デー 夕と併用することで, 北陸地方内の異なる気象条件下で湛 水直播栽培したイネの出芽・苗立ちの播種早限を推定でき る可能性を示している。播種早限の推定に関して, 古畑・ 原 (2013) は，北陸地方の各アメダス観測地点の 4 月から 6 月上旬の平均気温, 最高気温, 最低気温の平年值から, 播 種後 20 日間の平均気温が $15^{\circ} \mathrm{C}$ となる最初の日と, アレニ ウス式に従う原の式（2010）を利用して20日間の変換日 数（ある温度で一定の日数を経過したときに影響の程度を 標準温度での日数に換算して 20 日分積算した值）を求め, 平均気温 $15^{\circ} \mathrm{C}$ (昼温 $20^{\circ} \mathrm{C} \cdot$ 夜温 $10^{\circ} \mathrm{C}$ ) が 20 日間続いた場 合の変換日数の值 $(7.573)$ を超えた最初の日を計算してそ れぞれ早限日とした。その結果，内陸部で気温日較差が大 きくなる地域では播種を平均気温から推定される早限日か ら数日早めても同等の苗立ちが得られる可能性，逆に沿岸 部や気温日較差が小さい地域では平均気温から推定される 早限日に播種した場合，出芽・苗立ちが遅れて十分な苗立 ちを得られない可能性を報告している.

以上の結果, 低温条件下で過酸化カルシウムコーティン グ種子が気温日較差の大小によらず他の種子コーティング 処理より出芽・苗立ちが優れ，気温日較差の影響が小さい 
ことは，過酸化カルシウムコーティング直播栽培が寒冷地 での栽培に適していることを示唆している。,一方，種子の コーティング処理に関わらず，低温条件下での出芽・苗立 ちは気温日較差の影響を受けることから，寒冷地で過酸化 カルシウムコーティング種子を利用して湛水直播栽培を行 う場合でも，気温日較差を含めた気象条件に留意する必要 があると考えられた。

謝辞：本研究の遂行に当たり，近畿中国四国センターの 松村修氏には適切なご助言を頂いた。また，技術専門職の 栗㟝利幸氏にご協力頂いた。ここに記して感謝の意を表す る次第である。

\section{引用文献}

古畑昌巳 - 楠田宰 · 福嶌陽 2005. 水稲の湛水直播・落水栽培におけ る落水時期が出芽・苗立ちに及ぼす影響. 日作紀 74: 134-140. 古畑昌巳・帖佐直・松村修 2008. 鉄資材の被覆が湛水直播水稲の出芽. 苗立ちに及ぼす影響. 一種子予措の効果 -. 日作紀 77 (別 2): 6-7.

古畑昌巳・帖佐直・松村修・湯川智行 2009a. 鉄資材のコーティング が湛水直播水稲の出芽・苗立ちに及ぼす影響 一酸素発生資材との 比較一.日作紀 78: 170-179.

古畑昌巳・帖佐直・松村修・湯川智行 2009b. 異なる酸化程度とした
鉄コーティング種子が湛水直播水稲の出芽・苗立ちに及ぼす影響. 日作紀 78: 242-249.

古畑昌巳・原嘉隆 2013. アレニウス式とアメダス気象データを利用 した北陸地方における湛水直播栽培の播種早限の推定. 日作紀 82: 402-406.

古畑昌巳 · 原嘉隆 2014. 寒冷地における風等の気象条件が湛水直播の 出芽・苗立ちに及ぼす影響. 一異なる気温と気温日較差での解析一. 日作紀 83 (投稿中).

原嘉隆 2010. 日平均温度で算出した標準温度変換日数の過誤評価程 度と日較差を用いた補正. 日作紀 79: 342-350。

農林水産省 2013. 最新の直播の状況 (23 年産確定值). http://www. maff.go.jp/j/seisan/ryutu/zikamaki/z_genzyo/pdf/131209zikamakigenzyo. pdf $(2014 / 01 / 21$ 閲覧).

山内稔 2004. 水稲の鉄コーティング湛水直播. 農及園 80: 947-953.

山内稔 2005a.「動散で播く鉄コーティング種子 雑草と鳥害をクリ ア!」現代農業 84: 114-117.

山内稔 2005b. 浮き苗と鳥害を防ぎ，いつでもまける鉄コーティング 種子.「農業技術体系作物編 2 イネ. 基礎技術編」追録 27 号：技 402 の 7 の $2-8$.

吉永悟志 $\cdot$ 境谷栄二 · 吉田宏 $\cdot$ 山本晶子 若松一幸 $\cdot$ 菊池栄一 · 本 間昌直 2007. 東北地域の水稲湛水直播栽培に打ける酸素発生剂被 覆量と苗立ちとの関係. 日作紀 76: 445-449

Influence of Daily Temperature Range on Seedling Emergence and Establishment of Direct-Seeded Rice under Submerged Conditions in Cold-Climate Areas-Analysis using Different Coated Seeds under Low Temperature Conditions- : Masami Furuhata $^{1)}$ and Yoshitaka HARA ${ }^{2)}\left({ }^{1)}\right.$ NARO Agricultural Research Center Hokuriku Research Center, Joetsu 943-0193, Japan; ${ }^{2)}$ NARO Kyushu Okinawa Agricultural Research Center)

Abstract : Previously, we investigated seedling emergence and establishment of direct-seeded rice under different air temperature and daily temperature range conditions using pregerminated seeds. Our results showed that the influence of daily temperature range after seeding was greater under low than under high temperature conditions. Furthermore, the growth under low temperature conditions after seeding was promoted when the daily temperature range was wider. In the present study, we investigated seedling emergence and establishment of direct-seeded rice grown under different daily temperature ranges in low temperature conditions using calcium peroxide-coated, iron-coated, and non-coated seeds in an incubator. Calcium peroxidecoated seeds had the highest seedling emergence and establishment rates that were least influenced by the daily temperature range. In all types of seeds, the growth under low temperature conditions after seeding was better under a wider daily temperature range condition. Furthermore, seedling emergence rate estimated by the Arrhenius equation well simulated the measured value.

Key words : Arrhenius equation, Coated seed, Cold climate area, Daily temperature range, Direct seeding in flooded paddy field, Rice, Seedling emergence. 